\title{
Articles
}

Contribution from the Institute für Anorganische Chemie der Universität Göttingen, Tammannstrasse 4, D-3400 Göttingen, Federal Republic of Germany

\section{Preparation and Structural Characterization of the Bis[bis(trimethylsilyl)amido]chalcogenides of Selenium and Tellurium}

\author{
Már Björgvinsson, Herbert W. Roesky," Frank Pauer, Dietmar Stalke, and George M. Sheldrick
}

Received June 11, 1990

\begin{abstract}
The new compounds $\mathrm{Se}\left[\mathrm{N}\left(\mathrm{SiMe}_{3}\right)_{2}\right]_{2}$ and $\mathrm{Te}\left[\mathrm{N}\left(\mathrm{SiMe}_{3}\right)_{2}\right]_{2}$ have been prepared in relatively good yields and their crystal structures determined by $\mathrm{X}$-ray crystallography at low temperature. The Se compound crystallizes in the monoclinic system, space group $C 2 / c$, with $Z=4$ and unit cell dimensions $a=1705.4(3) \mathrm{pm}, b=642.2(2) \mathrm{pm}, c=2116.7(4) \mathrm{pm}$, and $\beta=108.19(2)^{\circ}$. The Te compound crystallizes in the triclinic system, space group $P \mathrm{I}$, with $Z=2$ and unit cell dimensions $a=903.9$ (3) pm, $b=1111.7$ (4) pm, $c=1241.0(4) \mathrm{pm}, \alpha=88.67(2)^{\circ}, \beta=73.68(3)^{\circ}$, and $\gamma=69.10(2)^{\circ}$. The crystals of both compounds consist of isolated $\mathrm{Ch}\left[\mathrm{N}\left(\mathrm{SiMe}_{3}\right)_{2}\right]_{2}(\mathrm{Ch}=\mathrm{Se}, \mathrm{Te})$ molecules containing V-shaped $\mathrm{ChN}_{2}$ units with Se-N distances of 186.9 (2) pm and Te-N distances of 205.3 (2) and $204.5(2) \mathrm{pm}$. The $\mathrm{NChN}$ bond angles were found to be $108.0(1)$ and $105.8(1)^{\circ}$ for the Se and Te compounds, respectively. No significant intermolecular $\mathrm{Ch} \cdots \mathrm{N}$ interactions were found in the two compounds, but an intermolecular Te...Te distance of $377 \mathrm{pm}$, substantially less than the corresponding van der Waals distance, is present in the Te compound.
\end{abstract}

\section{Introduction}

Over the past few decades a large number of sulfur-nitrogen (S-N) compounds have been prepared, displaying diversity of structures and physical properties. ' In contrast, few seleniumnitrogen (Se-N) and even fewer tellurium-nitrogen compounds $(\mathrm{Te}-\mathrm{N})$ have been structurally characterized. Recently, however, there has been a growing interest in $\mathrm{Se}-\mathrm{N}^{2}$ and $\mathrm{Te}-\mathrm{N}^{3}$ structures. Many of these compounds have novel ring or cage structures such as $\left(\mathrm{Ph}_{2} \mathrm{C}_{2} \mathrm{~N}_{3} \mathrm{Se}\right)_{2},{ }^{2 \mathrm{c}} \quad\left[\mathrm{Pt}\left(\mathrm{Se}_{2} \mathrm{~N}_{2} \mathrm{H}\right)\left(\mathrm{PMe} \mathrm{Ph}_{2} \mathrm{Ph}\right)_{2} \mathrm{Cl}^{2 \mathrm{~d}}[\mathrm{SeN}\right.$ $\left.\mathrm{SeNSe}^{2+}\right]\left[\mathrm{AsF}_{6}{ }^{-}\right]_{2},{ }^{2 e}(t-\mathrm{BuN})_{2} \mathrm{Se}_{6},{ }^{2 \mathrm{~g}}(t-\mathrm{BuN})_{6} \mathrm{Se}_{9},{ }^{2 \mathrm{~B}}$ and $\mathrm{N}(\mathrm{Te}-$ (NSN)Cl) 3 .3DMF. ${ }^{3 \mathrm{i}}$

Undoubtedly, one of the main Achilles' heels in the preparation of new Se-N and Te-N compounds has been the lack of suitable stable precursors that can be prepared in good yields. For example, preparations of Se-N and Te-N compounds have often been limited to reactions of amine derivatives with the corresponding chalcogen halogenides or by the use of the explosive $\mathrm{Se}_{4} \mathrm{~N}_{4}$. We therefore wish to report our recent success in preparing and characterizing the new and stable compounds $\mathrm{Se}\left[\mathrm{N}\left(\mathrm{SiMe}_{3}\right)_{2}\right]_{2}$ (1) and $\mathrm{Te}\left[\mathrm{N}\left(\mathrm{SiMe}_{3}\right)_{2}\right]_{2}(2)$. During the preparation of this paper, we learned of a recent report by Haas et al., ${ }^{4}$ which describes a

(1) Sulfur-Nitrogen Compounds. In Gmelin Handbook of Inorganic Chemistry; Springer-Verlag: Berlin, 1977, 1985, 1987, 1990; Parts 1-5.

(2) (a) Gieren, A.; Lamm, V.; Haddon, R. C.; Kaplan, M. L. J. Am. Chem Soc. 1980, 102, 5070. (b) Haas, A.; Kasprowski, J. Chimia 1987, 41 , 340. (c) Oakley, R. T.; Reed, R. W.; Cordes, A. W.; Craig, S. L.; Graham, J. B. J. Am. Chem. Soc. 1987, 109, 7745. (d) Kelly, P. F; Parkin, I. P.; Slawin, A. M. Z.; Williams, D. J.; Woollins, J. D. Angew. Chem. 1989, 101, 1052; Angew. Chem., Int. Ed. Engl. 1989, 28, 1047. (e) Awere, E. G.; Passmore, J.; White, P. S.; Klapötke, T. J. Chem. Soc., Chem. Commun. 1989, 1415. (f) Gillespie, R. J.; Kent, J. P.; Sawyer, J. F. Inorg. Chem. 1990, 29, 1251. (g) Roesky, H. W.; Weber, K. L.; Bats, J. W. Chem. Ber. 1984, 117, 2686. (h) Roesky, H. W. Weber, K. L.; Seseke, U.; Pinkert, W.; Noltemeyer, M.; Clegg, W.; Sheldrick, G. M. J. Chem. Soc. Dalion Trans. 1985, 565.

(3) (a) Betini, V.; Dapporto, P.; Lucchesini, F.; Sega, A.; De Munno, A Acta Crystallogr. 1984, C40, 653. (b) Neidlein, R.: Knecht, D.: Gieren. A.: Ruiz-Përez, C. Z. Naturforsch. 1987, 42B, 84. (c) Hartl, H.; Huppmann, P.; Lentz, D.; Seppelt, K. Inorg. Chem. 1983, 22, 2183. (d) Thrasher, J. S.: Nielsen, J. B.; Bott, S. G.; McClure, D. J.; Morris, S. A.: Atwood, J. L. Inorg. Chem. 1988, 27, 570. (e) Hey, E.; Ergezinger C.: Dehnicke, K. 2. Naturforsch. 1989, 44B, 205. (f) Münzenberg, J. Noltemeyer, M.; Roesky, H. W. Chem. Ber. 1989, 122, 1915. (g) Johnson, J. P.; MacLean, G. K.; Passmore, J.; White, P. S. Can. J Chem. 1989, 67, 1687. (h) Haas, A., Pohl, R. Chimia 1989, 43, 261 (i) Roesky, H. W.; Münzenberg, J.; Noltemeyer, M. Angew. Chem 1990, 102, 73: Angew. Chem Int Ed Engl 1990, 29,61.

(4) Haas, A.: Kasprowski, J. Chimia 1990, 44, 57. synthesis of 1 comparable to our work.

\section{Results and Discussion}

Preparation of 1 and 2. Compounds 1 and 2 were prepared in good yields (50-75\%) according to eqs 1 and 2 , respectively.

$$
\begin{array}{r}
2 \mathrm{LiN}\left(\mathrm{SiMe}_{3}\right)_{2}+\mathrm{Se}_{2} \mathrm{Cl}_{2} \underset{-2 \mathrm{LiCl},-1 / 8 \mathrm{Se}_{8}}{\longrightarrow} \mathrm{Se}\left[\mathrm{N}\left(\mathrm{SiMe}_{3}\right)_{2}\right]_{2} \\
4 \mathrm{LiN}\left(\mathrm{SiMe}_{3}\right)_{2}+\mathrm{TeCl}_{4} \underset{-\mathrm{LiCl}}{\longrightarrow} \mathrm{Te}\left[\mathrm{N}\left(\mathrm{SiMe}_{3}\right)_{2}\right]_{2}
\end{array}
$$

As can be seen from eq $1, \mathrm{Se}_{2} \mathrm{Cl}_{2}$ reacts as effectively as $\mathrm{SeCl}_{2}$ with $\mathrm{LiN}\left(\mathrm{SiMe}_{3}\right)_{2}$ to form 1 with a corresponding formation of $\mathrm{Se}_{8}$. This is not surprising, as there is evidence from ${ }^{77} \mathrm{Se} \mathrm{NMR}$ and Raman studies that $\mathrm{Se}_{2} \mathrm{Cl}_{2}$ is in equilibrium with $\mathrm{SeCl}_{2}$ and $\mathrm{Se}_{n} \mathrm{Cl}_{2}(n>2)$, indicating relatively labile $\mathrm{Se}-\mathrm{Cl}$ bonds for these species in solution. ${ }^{5}$ Haas et al. ${ }^{4}$ recently synthezised 1 by reacting $\mathrm{LiN}\left(\mathrm{SiMe}_{3}\right)_{2}$ with $\mathrm{Se}_{2} \mathrm{Cl}_{2}$. In addition, they report that $\mathrm{Se}_{2}[\mathrm{~N}$ $\left.\left(\mathrm{SiMe}_{3}\right)_{2}\right]_{2}$ is also formed and that $\mathrm{SiMe}_{3} \mathrm{Cl}$ forms instead of the expected $\mathrm{LiCl}$. However, as reaction conditions are not reported, we cannot comment on these differences from our work.

The mechanism for the reduction of $\mathrm{TeCl}_{4}$ to 2 is, however, not fully understood. It was found that, in order to minimize substitution reactions of $\mathrm{N}-\mathrm{SiMe}_{3}$ groups with $\mathrm{Te}-\mathrm{Cl}$ bonds, $\mathrm{LiN}\left(\mathrm{SiMe}_{3}\right)_{2}$ must be kept in excess relative to $\mathrm{TeCl}_{4}$ (mole ratio $4: 1$ ) in the reaction mixture in order to prevent consequent formation of elemental tellurium. It is conceivable that $\mathrm{Te}[\mathrm{N}$ $\left.\left(\mathrm{SiMe}_{3}\right)_{2}\right]_{4}$ is initially formed, which then decomposes to 2 and $\mathrm{N}\left(\mathrm{SiMe}_{3}\right)_{2}$ radicals. The $\mathrm{N}\left(\mathrm{SiMe}_{3}\right)_{2}$ radicals so formed could then in turn abstract hydrogen atoms from the solvent ( $n$-hexane/toluene mixture). However, irrespective of the initial species formed, the presence of radical reactions are supported by the fact that a relatively large amount of $\mathrm{HN}\left(\mathrm{SiMe}_{3}\right)_{2}$ could be identified by 'H NMR spectroscopy, along with other unidentified species, in the volatile component of the reaction mixture. No $\mathrm{SiMe}_{3} \mathrm{Cl}$ was evident in the volatile component.

Compounds 1 and 2 could be isolated and purified by sublimation and were easily characterized by using mass spectroscopy by comparison of the measured and calculated isotopomer mass pattern of their relative intense molecular peaks.

Crystal Structures of $\mathbf{1}$ and 2. In order to determine the detailed molecular structures of 1 and 2 , their crystal structures were determined by single-crystal X-ray diffraction analysis. The crystal

(5) Lamouoeux, M.; Milne, J. Can. J. Chem. 1989, 67, 1936. 
Table I. Crystallographic Data for 1 and 2

\begin{tabular}{|c|c|c|}
\hline & 1 & 2 \\
\hline $\begin{array}{l}\text { formula } \\
\mathrm{fw}\end{array}$ & $\begin{array}{l}\mathrm{C}_{12} \mathrm{H}_{36} \mathrm{~N}_{2} \mathrm{Si}_{4} \mathrm{Se} \\
399.7\end{array}$ & $\begin{array}{l}\mathrm{C}_{12} \mathrm{H}_{36} \mathrm{~N}_{2} \mathrm{Si}_{4} \mathrm{Te} \\
448.4\end{array}$ \\
\hline data collen $\mathrm{T},{ }^{\circ} \mathrm{C}$ & -120 & -120 \\
\hline cryst size, mm & $0.6 \times 0.6 \times 0.7$ & $0.7 \times 0.7 \times 0.8$ \\
\hline space group & $C 2 / c$ & $P \overline{1}$ \\
\hline$a, \mathrm{pm}$ & $1705.4(3)$ & $903.9(3)$ \\
\hline$b, \mathrm{pm}$ & $642.4(2)$ & $1111.7(4)$ \\
\hline$c, \mathrm{pm}$ & $2116.7(4)$ & $1241.0(4)$ \\
\hline$\alpha, \operatorname{deg}$ & 90 & $88.67(2)$ \\
\hline$\beta, \operatorname{deg}$ & $108.19(2)$ & $73.68(3)$ \\
\hline$\gamma, \operatorname{deg}$ & 90 & $69.10(2)$ \\
\hline cell vol, $\mathrm{nm}^{3}$ & 2.203 & 1.114 \\
\hline formula units/cell $(Z)$ & 4 & 2 \\
\hline calc density $\rho, \mathrm{Mg} \mathrm{m}^{-3}$ & 1.205 & 1.337 \\
\hline abs coeff $\mu, \mathrm{mm}^{-1}$ & 1.75 & 1.54 \\
\hline$F(000)$ & 848 & 460 \\
\hline measd $2 \theta$ range, deg & $8-55$ & $8-50$ \\
\hline no. of measd rflns & 3936 & 5044 \\
\hline no. of unique rflns & 2538 & 3906 \\
\hline no. of obsd rflns & 2261 & 3857 \\
\hline consistency of equiv rflns $\left(R_{\text {int }}\right)$ & 0.0220 & 0.0202 \\
\hline$p(F>p \sigma(F))$ & 3 & 3 \\
\hline$R$ & 0.0281 & 0.0169 \\
\hline$R_{\mathrm{w}}$ & 0.0286 & 0.0175 \\
\hline goodness-of-fit wtg factor $g$ & 1.4843 & 2.1374 \\
\hline$w=1 /\left(\sigma^{2}(F)+\operatorname{abs}(g) F^{2}\right.$ & 0.0002 & 0.00001 \\
\hline $\begin{array}{l}\text { no. of refined params } \\
\text { last diff Fourier synthesis }\end{array}$ & 87 & 172 \\
\hline $\begin{array}{l}\text { last diff Fourier synthesis } \\
\text { highest } \max ,\left[\mathrm{e}^{-} \mathrm{nm}^{3}\right]:\end{array}$ & $3.6 \times 10^{2}$ & $7.6 \times 10^{2}$ \\
\hline lowest min, $\left[\mathrm{e}^{-} \mathrm{nm}^{-3}\right]$ : & $5.3 \times 10^{2}$ & $4.2 \times 10^{2}$ \\
\hline abs cor & semiempirical & semiempirical \\
\hline
\end{tabular}

Table II. Atomic Coordinates $\left(\times 10^{4}\right)$ and Equivalent Isotropic Displacement Parameters $\left(\mathrm{pm}^{2} \times 10^{-1}\right)^{a}$ for 1

\begin{tabular}{lllll}
\hline & $x$ & $y$ & $z$ & $U(\mathrm{eq})$ \\
\hline $\mathrm{Se}(1)$ & 5000 & $5048(1)$ & 2500 & $25(1)$ \\
$\mathrm{N}(1)$ & $5173(1)$ & $3338(3)$ & $3245(1)$ & $25(1)$ \\
$\mathrm{Si}(1)$ & $6116(1)$ & $3611(1)$ & $3881(1)$ & $28(1)$ \\
$\mathrm{C}(11)$ & $6900(1)$ & $5014(4)$ & $3599(1)$ & $43(1)$ \\
$\mathrm{C}(12)$ & $6553(1)$ & $1027(4)$ & $4210(1)$ & $43(1)$ \\
$\mathrm{C}(13)$ & $5960(2)$ & $5151(4)$ & $4581(1)$ & $43(1)$ \\
$\mathrm{Si}(2)$ & $4258(1)$ & $2362(1)$ & $3348(1)$ & $27(1)$ \\
$\mathrm{C}(21)$ & $3560(1)$ & $4528(3)$ & $3401(1)$ & $40(1)$ \\
$\mathrm{C}(22)$ & $3746(1)$ & $547(4)$ & $2662(1)$ & $41(1)$ \\
$\mathrm{C}(23)$ & $4491(1)$ & $816(4)$ & $4129(1)$ & $42(1)$
\end{tabular}

${ }^{a}$ Equivalent isotropic $U$ defined as one-third of the trace of the orthogonalized $\mathbf{U}_{i j}$ tensor.

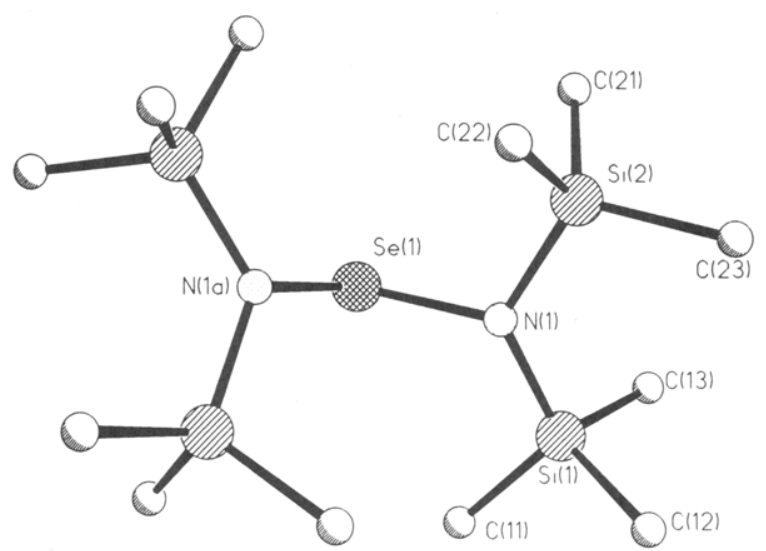

Figure 1. Molecular structure and partial numbering scheme of $\mathrm{Se}[\mathrm{N}$ $\left.\left(\mathrm{SiMe}_{3}\right)_{2}\right]_{2}(\mathbf{1})$. For clarity, the hydrogen atoms have been omitted.

data for $\mathbf{1}$ and $\mathbf{2}$ are given in Table I, the fractional coordinates in Tables II (1) and III (2), and selected bond distances, bond angles, and torsional angles in Table IV (1 and 2).

The crystals of $\mathbf{1}$ and $\mathbf{2}$ consist of isolated molecules whose structures are shown in Figures 1 (1) and 2 (2). The average $\mathrm{Se}-\mathrm{N}$ $(187 \mathrm{pm})$ and $\mathrm{Te}-\mathrm{N}(205 \mathrm{pm})$ distances for 1 and 2 correspond
Table III. Atomic Coordinates $\left(\times 10^{4}\right)$ and Equivalent Isotropic Displacement Parameters $\left(\mathrm{pm}^{2} \times 10^{-1}\right)^{a}$ for 2

\begin{tabular}{lcrrr}
\hline \multicolumn{1}{c}{$x$} & \multicolumn{1}{c}{$y$} & \multicolumn{1}{c}{$z$} & $U(\mathrm{eq})$ \\
\hline $\mathrm{Te}(1)$ & $5233(1)$ & $5922(1)$ & $3707(1)$ & $22(1)$ \\
$\mathrm{N}(1)$ & $5551(2)$ & $4365(1)$ & $2688(1)$ & $23(1)$ \\
$\mathrm{Si}(1)$ & $7401(1)$ & $3021(1)$ & $2447(1)$ & $23(1)$ \\
$\mathrm{C}(11)$ & $6994(3)$ & $1670(2)$ & $3250(2)$ & $35(1)$ \\
$\mathrm{C}(12)$ & $8986(2)$ & $3362(2)$ & $2948(2)$ & $35(1)$ \\
$\mathrm{C}(13)$ & $8342(3)$ & $2439(2)$ & $924(2)$ & $39(1)$ \\
$\mathrm{Si}(2)$ & $3732(1)$ & $4338(1)$ & $2463(1)$ & $25(1)$ \\
$\mathrm{C}(21)$ & $2914(3)$ & $5690(2)$ & $1623(2)$ & $37(1)$ \\
$\mathrm{C}(22)$ & $2164(3)$ & $4409(3)$ & $3826(2)$ & $52(1)$ \\
$\mathrm{C}(23)$ & $4139(3)$ & $2841(2)$ & $1598(2)$ & $44(1)$ \\
$\mathrm{N}(2)$ & $4920(2)$ & $7449(1)$ & $2732(1)$ & $22(1)$ \\
$\mathrm{Si}(3)$ & $3015(1)$ & $8758(1)$ & $3090(1)$ & $23(1)$ \\
$\mathrm{C}(31)$ & $1313(2)$ & $8346(2)$ & $4063(2)$ & $31(1)$ \\
$\mathrm{C}(32)$ & $3199(3)$ & $10125(2)$ & $3826(2)$ & $37(1)$ \\
$\mathrm{C}(33)$ & $2350(3)$ & $9329(2)$ & $1807(2)$ & $41(1)$ \\
$\mathrm{Si}(4)$ & $6800(1)$ & $7558(1)$ & $1926(1)$ & $25(1)$ \\
$\mathrm{C}(41)$ & $6445(3)$ & $8964(2)$ & $1048(2)$ & $39(1)$ \\
$\mathrm{C}(42)$ & $8004(3)$ & $6097(2)$ & $921(2)$ & $38(1)$ \\
$\mathrm{C}(43)$ & $8025(3)$ & $7748(2)$ & $2849(2)$ & $46(1)$
\end{tabular}

${ }^{a}$ Equivalent isotropic $U$ defined as one-third of the trace of the orthogonalized $\mathbf{U}_{i j}$ tensor.

Table IV. Selected Bond Lengths (pm), Bond Angles (deg), and Torsion Angles (deg) for 1 and 2

\begin{tabular}{|c|c|c|c|}
\hline \multicolumn{4}{|c|}{ Bond Lengths } \\
\hline \multicolumn{2}{|c|}{1} & \multicolumn{2}{|c|}{2} \\
\hline $\operatorname{Se}(1)-N(1)$ & 186.9 (2) & $\operatorname{Te}(1)-\mathrm{N}(1)$ & $205.3(2)$ \\
\hline $\mathrm{N}(1)-\mathrm{Si}(1)$ & $175.3(1)$ & $\mathrm{Te}(1)-\mathrm{N}(2)$ & $204.5(2)$ \\
\hline \multirow[t]{4}{*}{$\mathrm{N}(1)-\mathrm{Si}(2)$} & $175.8(2)$ & $\mathrm{N}(1)-\mathrm{Si}(1)$ & $175.3(1)$ \\
\hline & & $N(1)-S i(2)$ & $175.4(2)$ \\
\hline & & $\mathrm{N}(2)-\mathrm{Si}(3)$ & $175.9(1)$ \\
\hline & & $N(2)-S i(4)$ & $175.7(2)$ \\
\hline
\end{tabular}

\begin{tabular}{ccccc}
\multicolumn{5}{c}{ Bond Angles } \\
\hline \multicolumn{1}{c}{1} & & \multicolumn{2}{c}{$\mathbf{2}$} \\
\cline { 1 - 2 }$(1)-\mathrm{Se}(1)-\mathrm{N}(1 \mathrm{a})$ & $108.0(1)$ & & $\mathrm{N}(1)-\mathrm{Te}(1)-\mathrm{N}(2)$ & $105.8(1)$ \\
$\mathrm{Se}(1)-\mathrm{N}(1)-\mathrm{Si}(1)$ & $117.0(1)$ & $\mathrm{Te}(1)-\mathrm{N}(1)-\mathrm{Si}(1)$ & $118.1(1)$ \\
$\mathrm{Se}(1)-\mathrm{N}(1)-\mathrm{Si}(2)$ & $113.7(1)$ & $\mathrm{Te}(1)-\mathrm{N}(1)-\mathrm{Si}(2)$ & $114.9(1)$ \\
$\mathrm{Si}(1)-\mathrm{N}(1)-\mathrm{Si}(2)$ & $125.3(1)$ & $\mathrm{Si}(1)-\mathrm{N}(1)-\mathrm{Si}(2)$ & $124.6(1)$ \\
& & $\mathrm{Te}(1)-\mathrm{N}(2)-\mathrm{Si}(3)$ & $119.3(1)$ \\
& & $\mathrm{Te}(1)-\mathrm{N}(2)-\mathrm{Si}(4)$ & $113.1(1)$ \\
& & $\mathrm{Si}(3)-\mathrm{N}(2)-\mathrm{Si}(4)$ & $123.9(1)$
\end{tabular}

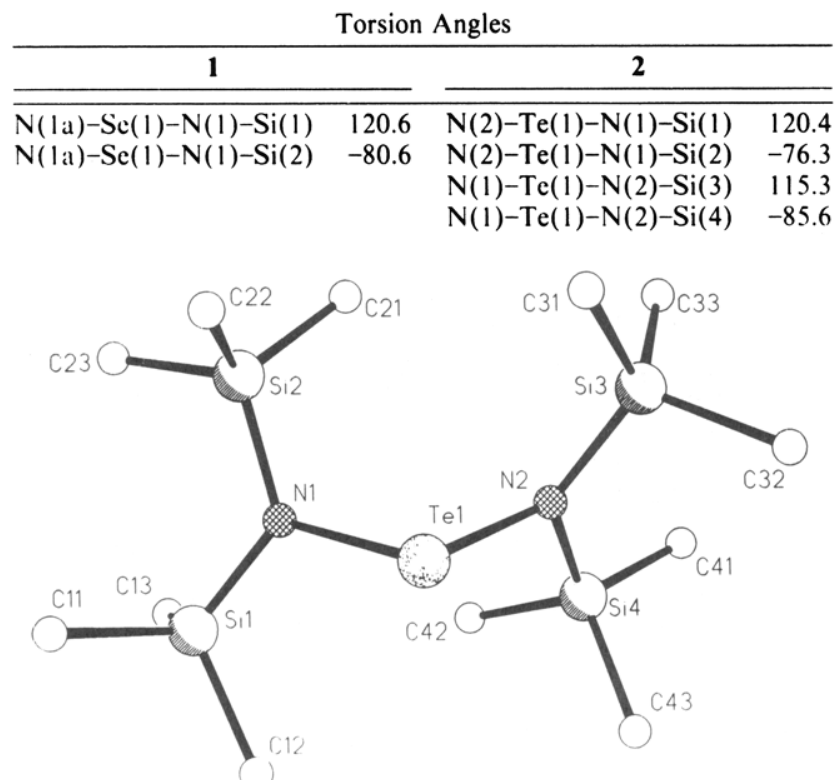

Figure 2. Molecular structure and partial numbering scheme of Te[N$\left.\left(\mathrm{SiMe}_{3}\right)_{2}\right]_{2}(2)$. The hydrogen atoms have been omitted for clarity. well to Pauling's single-bond lengths of 186 and 204 pm, respectively. ${ }^{6}$ Reported Se-N bond lengths vary from 168 to 190 


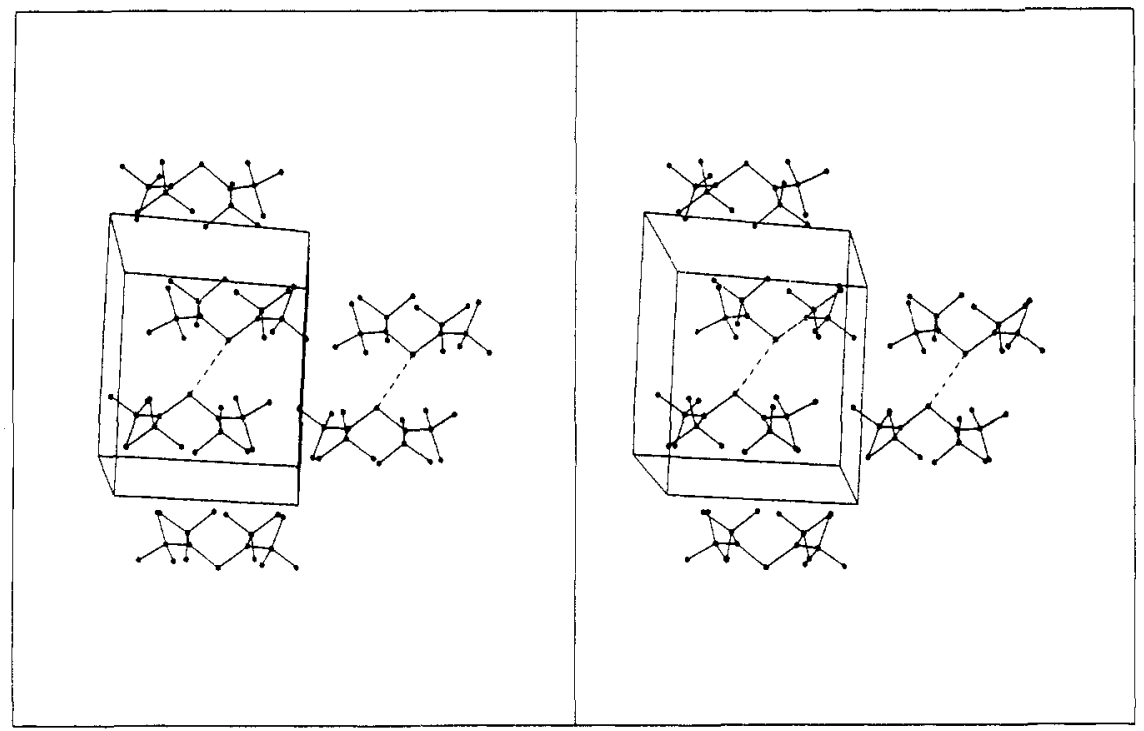

Figure 3. Stereoscopic view of the crystal packing of $\mathrm{Te}\left[\mathrm{N}\left(\mathrm{SiMe}_{3}\right)_{2}\right]_{2}(2)$. The broken lines show the relative short intermolecular Te...Te distances in the crystal (see text).

pm. ${ }^{2}$ However, the $\mathrm{Se}-\mathrm{N}$ distance of 1 corresponds better with the range of 181-190 pm for $\mathrm{Se}(\mathrm{II})-\mathrm{N}$ bond lengths. ${ }^{2 \mathrm{a}, \mathrm{b}, \mathrm{g}}$ The $\mathrm{Te}-\mathrm{N}$ distances of 2 fall within the range of $198-210 \mathrm{pm}$ reported for most other $\mathrm{Te}-\mathrm{N}$ covalent bonds. ${ }^{3}$ The pyramidal $\mathrm{NSi}_{2} \mathrm{Ch}$ units of 1 and 2 were found to be relatively flat with nitrogen atoms, on the average, $21 \mathrm{pm}$ (1) and $19 \mathrm{pm}$ (2) above their respective $\mathrm{Si}_{2} \mathrm{Ch}$ planes. The average $\mathrm{SiNSi}$ bond angles of $125^{\circ}$ (1) and $124^{\circ}(2)$ are larger than the average $\mathrm{SiNCh}$ bond angles of 115 and $116^{\circ}$ for 1 and 2 , respectively. The NSeN bond angle $\left(108^{\circ}\right)$ of 1 is larger than the NTeN bond angle $\left(106^{\circ}\right)$ of 2 , as expected on the basis of the VSEPR rules, ${ }^{7}$ owing to the greater electronegativity of Se relative to that of $\mathrm{Te}$.

Interestingly, even though a large number of compounds containing $\mathrm{N}\left(\mathrm{SiMe}_{3}\right)_{2}$ groups as ligands have been structurally characterized, ${ }^{8}$ only the structure of $\mathrm{S}\left[\mathrm{N}\left(\mathrm{SiMe}_{3}\right)_{2}\right]_{2}(3)^{9}$ has been reported for the group 16 elements. As expected, 3 has the same molecular structure as $\mathbf{1}$ and $\mathbf{2}$ and shows similar geometric trends. Thus, the $\mathrm{NSi}_{2} \mathrm{~S}$ pyramidal units of 3 are also relatively flat with average SiNS $\left(116^{\circ}\right)$ and $\mathrm{SiNSi}\left(124^{\circ}\right)$ bond angles similar to those of 1 and 2 . The NSN bond angle $\left(110^{\circ}\right)$ of 3 is significantly larger than the NChN bond angles of 1 and 2 . As above, this could be rationalized on the basis of the VSEPR rules if one assumes Pauling's electronegativity order: $\mathrm{S}>\mathrm{Se}>\mathrm{Te}$. However, the $\mathrm{S}-\mathrm{N}$ distances $(172 \mathrm{pm})$ of 3 indicate a small amount of double-bond character by comparison with Pauling's S-N single-bond distance $(174 \mathrm{pm})^{6}$ and could therefore also contribute to the observed larger NSN bond angle.

For both compounds 1 and 2 all the intermolecular Se... N and $\mathrm{Te}$-... $\mathrm{N}$ distances are longer than the corresponding van der Waals distances of 350 and $370 \mathrm{pm}$, respectively. ${ }^{6}$ The melting points of the bis[bis(trimethylsilyl)amido]chalcogenides $(\mathrm{Ch}=\mathrm{S}, \mathrm{Se}$, $\mathrm{Te})$ are low $\left(64-71^{\circ} \mathrm{C}\right)$ and do not change much with successive substitution of a chalcogen atom. The absence of significant $\mathrm{Ch}$... $\mathrm{N}$ intermolecular interactions in $\mathbf{1 - 3}$ is presumably due to the large size of the $\mathrm{N}\left(\mathrm{SiMe}_{3}\right)$, groups, which hinder their formation. Consequently, only the weaker van der Waals intermolecular interactions are dominant in the crystals of 1-3.

Interestingly, only in the crystals of $\mathrm{Te}\left[\mathrm{N}\left(\mathrm{SiMe}_{3}\right)_{2}\right]_{2}$ are relatively short intermolecular $\mathrm{Ch}$.... Ch distances found in the plane

(6) Pauling, L. The Nature of the Chemical Bond, 3rd ed.; Cornell University Press: Ithaca, NY, 1960; Chapter 7.

(7) Gillespie, R. J. Molecular Geometry; van Nostrand Reinhold: London, 1972 .

(8) Harris, D. H.: Lappert, M. F. In Journal of Organometallic Chemistry Library; Seyferth, D., Davies, A. G., Fischer, E. O., Normant, J. F., Reutov, O. A.. Eds.: Elsevier: Amsterdam, 1976; Vol. 2, pp 13-103.

(9) Schubert, G.; Kiel, G.; Gattow, G. Z. Anorg. Allg. Chem. 1989, 575 , 129. formed by two $\mathrm{TeN}_{2}$ units (Figure 3). The Te... Te distances of $377 \mathrm{pm}$ are shorter than the van der Waals distances of $440 \mathrm{pm}^{6}$ but can be compared with the interhelix chain Te...Te distances of $350 \mathrm{pm}$ in elemental tellurium. ${ }^{10}$ This is not surprising if one considers the greater size of the heavier Te atom and the increasing tendency of the heavier main-group elements to exhibit such interactions. However, as the long intermolecular Te...Te distances for $\mathbf{2}$ are dimeric in nature and do not lead to polymeric network in the crystal, the melting point of $\mathbf{2}$ is not drastically changed from that of 1 and 3.

\section{Conclusion}

The presence of $\mathrm{SiMe}_{3}$ groups bonded to the nitrogen atoms in 1 and $\mathbf{2}$ should allow a relatively convenient addition of $\mathrm{Se}-\mathrm{N}$ or $\mathrm{Te}-\mathrm{N}$ bonded units into new molecules by simple substitution reactions. Consequently, the relatively high-yield synthesis and isolation of the stable compounds 1 and $\mathbf{2}$ should render them as important starting materials for the synthesis of new $\mathrm{Se}-\mathrm{N}$ and $\mathrm{Te}-\mathrm{N}$ compounds.

\section{Experimental Section}

All manipulations were performed under an inert atmosphere of dry nitrogen gas in Schlenk apparatus or in a drybox. The $n$-hexane and toluene solvents were dried over $\mathrm{K} / \mathrm{Na}$ alloy and sodium metal, respectively, and distilled prior to use. The reagents $\mathrm{LiN}\left(\mathrm{SiMe}_{3}\right)_{2}$ and $\mathrm{Se}_{2} \mathrm{Cl}_{2}$ were prepared according to standard literature methods. The tellurium tetrachloride (Merck) was sublimed prior to use.

Mass spectra (EI) were obtained with a Varian CH-5 MAT instrument. Proton N.MR spectra (60 MHz) were recorded for 1 and 2 in $\mathrm{CCl}_{4}$ at room temperature with external $\mathrm{SiMe}_{4}$ as a reference. Elemental analyses were done by Beller Microanalytical Laboratory, Göttingen, FRG.

Warning! Owing to the relatively volatile nature of 1 and 2 and the toxicity of selenium and tellurium compounds, the following preparations should only be carried out in a well-ventilated fume hood.

SeiN(SiMe $\left.)_{2}\right]_{2}$ (1). To a magnetically stirred solution of $\mathrm{LiN}$ $\left(\mathrm{SiMe}_{3}\right)_{2}(3.08 \mathrm{~g}, 18.4 \mathrm{mmol})$ in $n$-hexane $(40 \mathrm{~mL})$ was added slowly at $-78{ }^{\circ} \mathrm{C} \mathrm{Se}_{2} \mathrm{Cl}_{2}(2.11 \mathrm{~g}, 9.2 \mathrm{mmol})$. The resulting yellow solution was stirred for $\mathrm{I} \mathrm{h}$ before being allowed to warm to room temperature. After being stirred further for $12 \mathrm{~h}$, the solution was filtered. The volatiles were then pumped off by using a liquid air trap system, and the yellow-orange oily solid residue was finally sublimed at $30-40^{\circ} \mathrm{C}$ under dynamic vacuum $(<0.1$ Torr $)$. Sublimation gave a total of $2.75 \mathrm{~g}(6.9 \mathrm{mmol}, 75 \%$ yield) of yellow crystalline product having a melting point of $64-65^{\circ} \mathrm{C}$. Anal. Found (calc for $\mathrm{H}_{36} \mathrm{C}_{12} \mathrm{~N}_{2} \mathrm{Si}$ Se): H, 8.94 (9.08); C, 36.20 (36.06); $\mathrm{N}, 7.11(7.01)$. ' $\mathrm{H}$ NMR $(\mathrm{ppm}): 0.27$. Mass spectrum (EI) $\left[\mathrm{m} / z{ }^{80} \mathrm{Se}\right.$ peaks, \%)]: $400\left(\mathrm{M}^{+}, 80\right), 275\left(\mathrm{M}^{+}-\mathrm{SeMe}_{2}-\mathrm{Me}, 45\right), 239\left(\mathrm{M}^{+}-\right.$ $\left.\mathrm{HN}\left(\mathrm{SiMe}_{3}\right)_{2}, 40\right)$. The yellow crystalline product can be purified further

(10) Greenwood, N. N.; Earnshaw, A. Chemistry of the Elements; Pergamon Press: Oxford, U.K., 1984; p 887 
by sublimation, giving colorless crystals having a melting point of $67^{\circ} \mathrm{C}$.

$\mathrm{Te}\left[\mathrm{N}\left(\mathrm{SiMe}_{3}\right)_{2}\right]_{2}$ (2). The procedure for the preparation of 2 was identical with that of 1 except freshly sublimed $\mathrm{TeCl}_{4}$ was first dissolved in toluene before being added to an $\mathrm{LiN}\left(\mathrm{SiMe}_{3}\right)_{2} / n$-hexane solution at $-78^{\circ} \mathrm{C}$. In a typical preparation using $1.10 \mathrm{~g}$ of $\mathrm{LiN}\left(\mathrm{SiMe}_{3}\right)_{2}(6.57$ $\mathrm{mmol})$ and $0.51 \mathrm{~g} \mathrm{of} \mathrm{TeCl}(1.89 \mathrm{mmol})$, a total of $0.43 \mathrm{~g}(0.97 \mathrm{mmol}$, $50 \%$ yield) of orange crystalline material having a melting point of 63-65 ${ }^{\circ} \mathrm{C}$ could be isolated by sublimation from the crude product. However. in order to obtain analytically pure product, the orange crystalline material had to be sublimed again twice $\left(\mathrm{mp} 69-71^{\circ} \mathrm{C}\right)$. Anal. Found (calc for $\mathrm{H}_{36} \mathrm{C}_{12} \mathrm{~N}_{2} \mathrm{Si}{ }_{4} \mathrm{Te}$ ): $\mathrm{H}, 8.17(8.09) ; \mathrm{C}, 32.48(32.15) ; \mathrm{N}, 6.28(6.25)$ ${ }^{1} \mathrm{H} N \mathrm{NMR}(\mathrm{ppm}): 0.24$. Mass spectrum (El) $\left[\mathrm{m} / \mathrm{z}\left({ }^{130} \mathrm{Te}\right.\right.$ peaks, \%)] $450\left(\mathrm{M}^{+}, 50\right), 289\left(\mathrm{M}^{+}-\mathrm{HN}\left(\mathrm{SiMe}_{3}\right)_{2}, 20\right), 275\left(\mathrm{M}^{+}-\mathrm{TeMe}_{2}-\mathrm{Me}\right.$ 100 ).

For analysis of the volatile components from the preparation of 2,2.56 $\mathrm{g}$ of $\mathrm{LiN}\left(\mathrm{SiMe}_{3}\right)_{2}(15.3 \mathrm{mmol})$ and $1.03 \mathrm{~g}$ of $\mathrm{TeCl}_{4}(3.81 \mathrm{mmol})$ were each added to separate arms of an $\mathrm{H}$-shaped greaseless reaction vessel After $\mathrm{LiN}\left(\mathrm{SiMe}_{3}\right)_{2}$ and $\mathrm{TeCl}_{4}$ had each been dissolved in $n$-hexane (20 $\mathrm{mL}$ ) and toluene $(20 \mathrm{~mL})$, respectively, the latter solution was decanted in small portions into the former at dry ice/acetone temperature. When the reaction was completed, the volatile components of the reaction mixture (at room temperature) were condensed into the empty ice/ water-cooled arm of the vessel. The presence of $\mathrm{HN}\left(\mathrm{SiMe}_{3}\right)_{2}$ and absence of $\mathrm{SiMe}_{3} \mathrm{Cl}$ in the volatile component were then identified by adding small amounts of them to a sample of the latter and recording their ${ }^{1} \mathrm{H}$ NMR spectra. A peak intensity enhancement was interpreted as a presence of the compound in the volatile component whereas a new peak indicated the compound's absence.

Crystal Growth and X-ray Measurements of 1 and 2. Crystals of 1 were grown over a period of 2-3 days by slowly condensing the solvent off an $n$-hexane solution of 1 . Crystals of 2 were grown overnight on the colder walls of a dynamically vacuum-pumped $(<0.1$ Torr) glass tube whose lower end, containing 2 , was kept in warm water $\left(30-40^{\circ} \mathrm{C}\right)$.

Both structures were measured on a Stoe-Siemens four-circle diffractometer with graphite-monochromated Mo $\mathrm{K} \alpha$ radiation $(\lambda=71.069$ $\mathrm{pm})$. Data were collected at $-120^{\circ} \mathrm{C}$ with a profile-fitting method, ${ }^{\prime \prime} 2 \theta$ $=8-55^{\circ}(1)$ and $8-50^{\circ}(2)$. The structures were solved by Patterson methods and refined by full-matrix least squares, with all non-hydrogen atoms anisotropic. All hydrogen atoms were found by difference Fourier synthesis and refined isotropically. A riding model was employed for the hydrogen atoms with an idealized bond length of $96 \mathrm{pm}$. A semiempirical absorption correction was applied in both cases. All calculations were performed with SHELX. ${ }^{12}$

Acknowledgment. We wish to thank the Leibniz-Programm der Deutschen Forschungsgemeinschaft and the Fonds der Chemischen Industrie for operating grants and the Alexander von Humboldt Foundation for the award of a fellowship to M.B.

Supplementary Material Available: Tables of bond lengths, bond angles, anisotropic displacement parameters, and $\mathrm{H}$ atom coordinates and isotropic displacement parameters (5 pages); listings of observed and calculated structural factors (2l pages). Ordering information is given on any current masthead page. Further details of the X-ray structural investigation can be obtained from the Fachinformationszentrum Karlsruhe, Gesellschaft für wissenschaftlich-technische Information $\mathrm{mbH}, \mathrm{D}-7514$ Eggenstein-Leopoldshafen 2, under quotation of the deposit number (CSD-54633), the authors, and the publication.

(11) Clegg, W. Acta Crystallogr. 1981, A37, 22

(12) Robinson, W.; Sheldrick, G. M. In SHELXS, Crystallographic Computing 4; Isaacs, N. W., Taylor, M. R., Eds.; Oxford University Press: London, 1988; pp 366-377.

\title{
Preparation and Structural Characterization of Two Isomers of Stoichiometry $\operatorname{Re}_{2} \mathrm{Cl}_{5}\left(\mathrm{PR}_{3}\right)_{3}$, Where $\mathrm{R}=\mathrm{Me}$ or $\mathrm{Et}$
}

\author{
F. Albert Cotton,* Andrew C. Price, and K. Vidyasagar
}

Received June 25, 1990

The paramagnetic dirhenium compounds of stoichiometry $\mathrm{Re}_{2} \mathrm{Cl}_{5}\left(\mathrm{PMe}_{3}\right)_{3}$ have been prepared from the reactions of $\mathrm{Re}_{2} \mathrm{Cl}_{4}\left(\mathrm{PMe}_{3}\right)_{4}$ with $\mathrm{Cl}_{2}(\mathrm{~g})$ or with $\mathrm{Phl} \cdot \mathrm{Cl}_{2}$. Two isomers have been isolated and their structures determined. In terms of a numbering system to be explained in the text, in one isomer, 1,3,6- $\mathrm{Re}_{2} \mathrm{Cl}_{5}\left(\mathrm{PMe}_{3}\right)_{3}(1)$, the two $\mathrm{PMe}$ ligands that are coordinated to a $\mathrm{Re}$ atom are trans to one another, while in the other isomer, 1,2,7- $\mathrm{Re}_{2} \mathrm{Cl}_{5}\left(\mathrm{PMe}_{3}\right)_{3}(2)$, the phosphines are cis. Attempts to convert the 1,2,7-isomer to the 1,3,6-isomer have been unsuccessful. A third compound, 1,3,6- $\operatorname{Re}_{2} \mathrm{Cl}_{5}\left(\mathrm{PEt}_{3}\right)_{3}$ (3) was isolated from the reaction between $\mathrm{Re}_{2} \mathrm{Cl}_{4}\left(\mathrm{PEt}_{3}\right)_{4}$ and $\mathrm{Ph}_{4} \mathrm{P}_{2}$. Pertinent crystal data are as follows: for 1, monoclinic space group $C 2 / c, a=13.157$ (2) $\AA$, $b=12.033(2) \AA, c=28.197$ (4) $\AA, \beta=92.84(1)^{\circ}, V=4459$ (1) $\AA^{3}, Z=8$; for 2 , monoclinic space group $P 2, / c, a=8.973$ (2) $\AA, b=8.752$ (1) $\AA, c=28.691$ (7) $\AA, \beta=90.21(2)^{\circ}, V=2253$ (1) $\AA^{3}, Z=4$; for $3, a=11.589$ (5) $\AA, b=14.795(4)$ $\AA, c=17.942(6) \AA, \beta=97.73(3)^{\circ}, V=3048(3) \AA^{3}, Z=4$

\section{Introduction}

Oxidative addition of halogens, disulfides, and diselenides to multiple metal-metal bonds is an area that has been explored in detail in this laboratory. ${ }^{\prime}$ For example, $\mathrm{Cl}_{2}(\mathrm{~g})$ reacts readily with compounds of the type $\mathrm{M}_{2} \mathrm{Cl}_{4}$ (dppe) $)_{2}(\mathrm{M}=\mathrm{Mo}$ or $\mathrm{W})$ to form the $\mathrm{M}_{2} \mathrm{Cl}_{6}$ (dppe) ${ }_{2}$ compounds. We carried out reactions of the triply bonded complex $\mathrm{Re}_{2} \mathrm{Cl}_{4}\left(\mathrm{PMe}_{3}\right)_{4}{ }^{2}$ with $\mathrm{Cl}_{2}(\mathrm{~g})$ (or with the use of $\mathrm{PhI} \cdot \mathrm{Cl}_{2}$, a solid chlorine equivalent) in the hope of obtaining a compound of stoichiometry $\operatorname{Re}_{2} \mathrm{Cl}_{6}\left(\mathrm{PMe}_{3}\right)_{4}$. This target molecule

(1) (a) Agaskar, P. A.; Cotton, F. A.; Dunbar, K. R.; Falvello, L. R.; O'Connor, C. J. Inorg. Chem. 1987, 26, 4051. (b) Canich, J. A. M. Cotton, F. A.: Dunbar, K. R.: Falvello, L. R. Inorg. Chem. 1988, 27, 804. (c) Cotton, F. A.; Dunbar, K. R. Inorg. Chem. 1987, 26, 1305.

(2) (a) Ebner, J. R.; Walton, R. A. Inorg. Chem. 1975, 14, 1987. (b) Root, D. R.; Blevins, C. H.; Lichtenberger, D. L.; Sattelberger, A. P.; Walton, R. A.J.Am. Chem. Soc. 1986, $103,953$. would be of interest with regard to a compound of similar stoichiometry, namely $\mathrm{Re}_{2} \mathrm{Cl}_{6}$ (dppe) ${ }_{2}$, which was reported several years ago by Walton and co-workers. ${ }^{3}$ This compound is quite unusual in that there is no $\operatorname{Re}-\operatorname{Re}$ bond and hence it would have been interesting to see if $\mathrm{Re}_{2} \mathrm{Cl}_{6}\left(\mathrm{PMe}_{3}\right)_{4}$ could adopt a similar structure. However, we have found that the reaction between $\mathrm{Re}_{2} \mathrm{Cl}_{4}\left(\mathrm{PMe}_{3}\right)_{4}$ and $\mathrm{Cl}_{2}$ (g) yields 1,3,6- $\mathrm{Re}_{2} \mathrm{Cl}_{5}\left(\mathrm{PMe}_{3}\right)_{3}$ (1) (an explanation of our numbering system will follow shortly). When the same reaction is carried out in the presence of $\mathrm{PMe}_{3}$, we obtained a different isomer, namely $1,2,7-\mathrm{Re}_{2} \mathrm{Cl}_{5}\left(\mathrm{PMe}_{3}\right)_{3}$ (2).

The numbering system that we are employing here to distinguish the two isomers is as follows. (1) Place the $\mathrm{Re}_{2}$ unit within a cube of ligands and number the latter in a clockwise direction as shown below:

(3) Jaecker, J. A.: Robinson, W. R.; Walton, R. A. J. Chem. Soc., Dalton Trans. 1975, 698 